\title{
Qualitative Content Analysis
}

\section{Philipp Mayring}

Key words:

qualitative content analysis, content analysis, category, induction,

intercoder-

reliability
Abstract: The article describes an approach of systematic, rule guided qualitative text analysis, which tries to preserve some methodological strengths of quantitative content analysis and widen them to a concept of qualitative procedure.

First the development of content analysis is delineated and the basic principles are explained (units of analysis, step models, working with categories, validity and reliability). Then the central procedures of qualitative content analysis, inductive development of categories and deductive application of categories, are worked out. The possibilities of computer programs in supporting those qualitative steps of analysis are shown and the possibilities and limits of the approach are discussed.

\section{Table of Contents}

1. Introduction

2. History of Content Analysis

3. Basic Ideas of Content Analysis

4. Procedures of Qualitative Content Analysis

5. Computer Programs for Support of Qualitative Content Analysis

6. Examples of Projects Working with Qualitative Content Analysis

7. Discussion

References

Author

Citation

\section{Introduction}

The qualitative content analysis (MAYRING 1983; 7th edition 2000), as it is presented here, consists in a bundle of techniques for systematic text analysis which we developed ca. 20 years ago in a longitudinal study about psycho-social consequences of unemployment (ULICH, HAUSSER, MAYRING et al. 1985). Conducting about 600 open-ended interviews we received more than 20.000 pages of transcripts which had to be analyzed in a qualitative oriented way. [1]

The main idea of the procedure of analysis is thereby, to preserve the advantages of quantitative content analysis as developed within communication science and to transfer and further develop them to qualitative-interpretative steps of analysis. [2]

Further information to quantitative content analysis are available via the Internet at http://www.gsu.edu/ wwwcom/content.html [Broken link, FQS, December 2004], http://www.zuma-mannheim.de/research/en/methods/textanalysis/ [broken 
link, September 2002, FQS] or

http://www.aber.ac.uk/media/Sections/textan01.html. [3]

The object of (qualitative) content analysis can be all sort of recorded communication (transcripts of interviews, discourses, protocols of observations, video tapes, documents ...). Content analysis analyzes not only the manifest content of the material—as its name may suggest. BECKER \& LISSMANN (1973) have differentiated levels of content: themes and main ideas of the text as primary content; context information as latent content. The analysis of formal aspects of the material belongs to its aims as well. As outlined below content analysis embeds the text into a model of communication within which it defines the aims of analysis. This is expressed by KRIPPENDORFF, who defines "content analysis as the use of replicable and valid method for making specific inferences from text to other states or properties of its source" (KRIPPENDORFF 1969, p.103). [4]

Qualitative content analysis defines itself within this framework as an approach of empirical, methodological controlled analysis of texts within their context of communication, following content analytical rules and step by step models, without rash quantification. [5]

\section{History of Content Analysis}

We can distinguish different phases in the historical background of content analysis (cf. MERTEN 1983; KRIPPENDORFF 1980; MAYRING 1994a):

- Precursors: We find different approaches to analysis and comparison of texts in hermeneutic contexts (e.g. bible interpretations) early newspaper analysis, graphological procedures, up to the dream analysis by Sigmund FREUD.

- Communication theoretical foundation: The basis of quantitative content analysis had been laid by Paul F. LAZARSFELD and Harold D. LASSWELL in USA during he 20ies and 30ies of 20th century. The first textbook about this method had been published (BERELSON 1952).

- Interdisciplinary broadening and differentiation: In the sixties of 20th century the methodological approach found its way into linguistics, psychology (cf. RUST 1983), sociology, history, arts etc. The procedures had been refined (fitting into different models of communication; analysis of non-verbal aspects, contingency analysis, computer applications) (cf. POOL 1959; GERBNER,HOLSTI, KRIPPENDORFF, PAISLEY \& STONE 1969).

- Phase of qualitative critics: Since the middle of 20th century objections were raised against a superficial analysis without respecting latent contents and contexts, working with simplifying and distorting quantification (KRACAUER 1952). In the following qualitative approaches to content analysis had been developed (RITSERT 1972; MOSTYN 1985; WITTKOWSKI 1994; ALTHEIDE 1996). [6] 


\section{Basic Ideas of Content Analysis}

If we say, qualitative content analysis wants to preserve the advantages of quantitative content analysis for a more qualitative text interpretation, so what are those advantages? I want to emphasize four points:

- Fitting the material into a model of communication: It should be determined on what part of the communication inferences shall be made, to aspects of the communicator (his experiences, opinions feelings), to the situation of text production, to the socio-cultural background, to the text itself or to the effect of the message.

- Rules of analysis: The material is to be analyzed step by step, following rules of procedure, devising the material into content analytical units.

- Categories in the center of analysis: The aspects of text interpretation, following the research questions, are putted into categories, which were carefully founded and revised within the process of analysis (feedback loops).

- Criteria of reliability and validity: The procedure has the pretension to be intersubjectively comprehensible, to compare he results with other studies in the sense of triangulation and to carry out checks for reliability. For estimating the inter-coder reliability we use in qualitative content analysis (in contrary to quantitative content analysis) only trained members of the project team and we reduce the standard of coder agreement (COHENS Kappa over .7 would be sufficient). [7]

\section{Procedures of Qualitative Content Analysis}

The above listed components of quantitative content analysis will be preserved to be the fundament for a qualitative oriented procedure of text interpretation. We developed a number of procedures of qualitative content analysis (cf. MAYRING 2000) amongst which two approaches are central: inductive category development and deductive category application. [8]

\subsection{Inductive category development}

Classical quantitative content analysis has few answers to the question from where the categories come, how the system of categories is developed: "How categories are defined ... is an art. Little is written about it" (KRIPPENDORF 1980, p.76). [9]

But within the framework of qualitative approaches it would be of central interest, to develop the aspects of interpretation, the categories, as near as possible to the material, to formulate them in terms of the material. For that scope qualitative content analysis has developed procedures of inductive category development, which are oriented to the reductive processes formulated within the psychology of text processing (cf. BALLSTAEDT, MANDL, SCHNOTZ \& TERGAN 1981; van DIJK 1980). [10] 


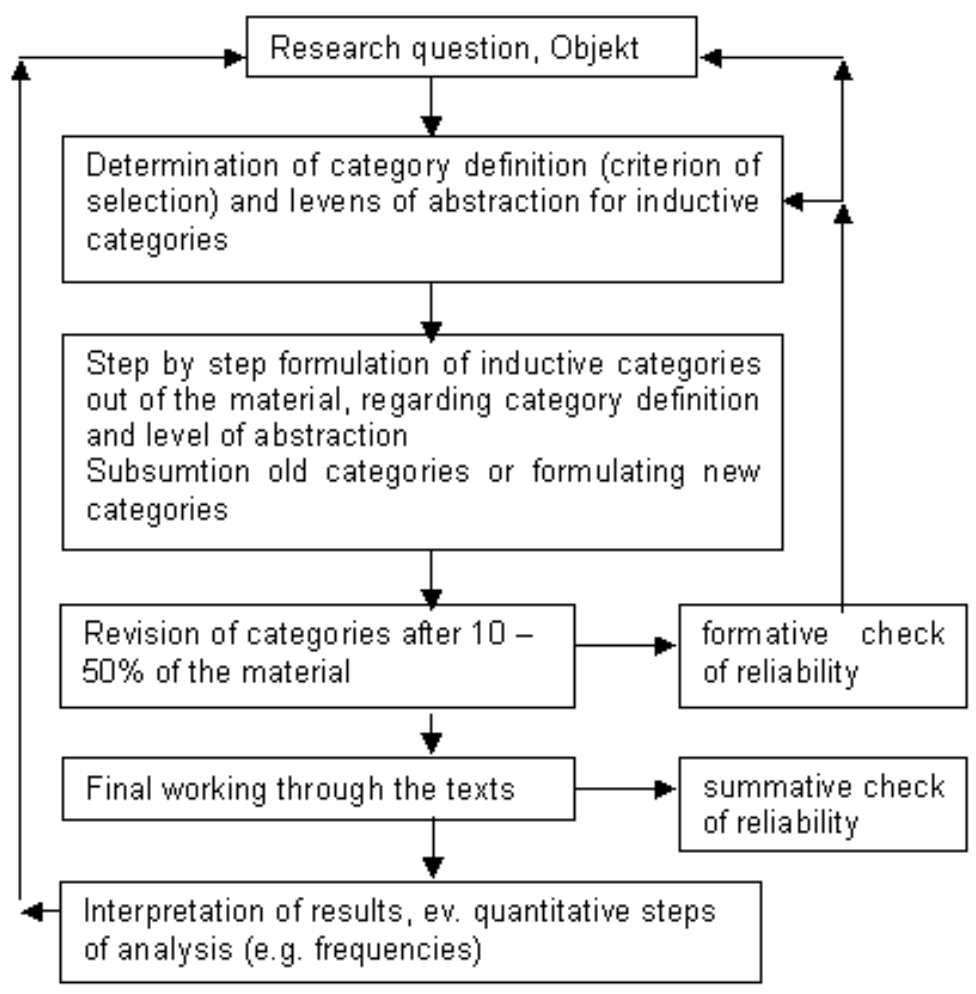

Fig. 1: Step model of inductive category development (MAYRING 2000) [11]

The specific steps cannot be explained largely within this short overview. The main idea of the procedure is, to formulate a criterion of definition, derived from theoretical background and research question, which determines the aspects of the textual material taken into account. Following this criterion the material is worked through and categories are tentative and step by step deduced. Within a feedback loop those categories are revised, eventually reduced to main categories and checked in respect to their reliability. If the research question suggests quantitative aspects (e.g. frequencies of coded categories) can be analyzed. [12]

\subsection{Deductive category application}

Deductive category application works with prior formulated, theoretical derived aspects of analysis, bringing them in connection with the text. The qualitative step of analysis consists in a methodological controlled assignment of the category to a passage of text. Even if several procedures of text analysis are processing that step, it is poorly described. Here the step model within qualitative content analysis: [13] 


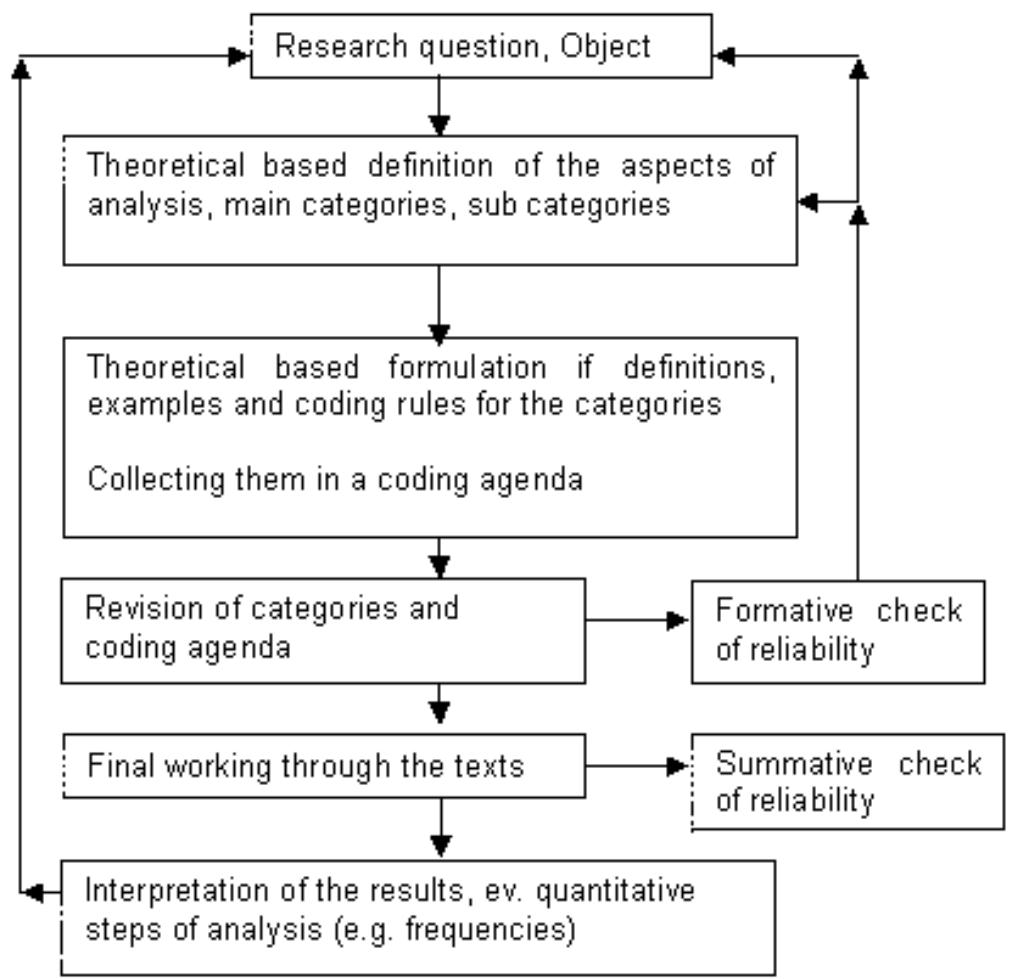

Fig.2: Step model of deductive category application (MAYRING 2000) [14]

Then main idea here is to give explicit definitions, examples and coding rules for each deductive category, determining exactly under what circumstances a text passage can be coded with a category. Those category definitions are putted together within a coding agenda. [15]

\begin{tabular}{|c|c|c|c|}
\hline Category & Definition & Examples & Coding Rules \\
\hline $\begin{array}{l}\text { C1: high self } \\
\text { confidence }\end{array}$ & $\begin{array}{l}\text { High subjective } \\
\text { conviction to have } \\
\text { successfully coped } \\
\text { with the situational } \\
\text { demands, which } \\
\text { means } \\
\text { - to be clear about the } \\
\text { demands and their } \\
\text { coping possibilities, } \\
\text { - to have a positive, } \\
\text { hopeful feeling in } \\
\text { handling the situation, } \\
\text { - to be sure to have } \\
\text { coped with the } \\
\text { demands on ones own } \\
\text { efforts. }\end{array}$ & $\begin{array}{l}\text { "Of course there had } \\
\text { been some little } \\
\text { problems, but we } \\
\text { solved them all, either I } \\
\text { myself or the student } \\
\text { gave in, depends who } \\
\text { made a mistake. } \\
\text { Everyone can make } \\
\text { mistakes." }(17,23) \\
\text { "Sure there had been } \\
\text { problems, but in the } \\
\text { end we had a fine } \\
\text { relationship. We got it } \\
\text { all together." }(27,33)\end{array}$ & $\begin{array}{l}\text { All three aspects of } \\
\text { thew definition have } \\
\text { to point to "high" self } \\
\text { confidence no aspect } \\
\text { only "middle" } \\
\text { Otherwise C2: middle } \\
\text { self confidence }\end{array}$ \\
\hline
\end{tabular}




\begin{tabular}{|c|c|c|c|}
\hline Category & Definition & Examples & Coding Rules \\
\hline $\begin{array}{l}\text { C2: middle self } \\
\text { confidence }\end{array}$ & $\begin{array}{l}\text { Only partly or } \\
\text { fluctuating conviction to } \\
\text { have successfully } \\
\text { coped with the } \\
\text { situational demands }\end{array}$ & $\begin{array}{l}\text { "Quite often I found it } \\
\text { hard to maneuver } \\
\text { through the problems, } \\
\text { but finally I made it." } \\
(13,45) \\
\text { "Time by time } \\
\text { everything got better, } \\
\text { but I couldn't tell if it } \\
\text { was me or the } \\
\text { circumstances." ( } 77 \text {, } \\
20)\end{array}$ & $\begin{array}{l}\text { If not all aspects of } \\
\text { definition point to } \\
\text { "High" or "low" }\end{array}$ \\
\hline $\begin{array}{l}\text { K3: low self } \\
\text { concept }\end{array}$ & $\begin{array}{l}\text { Conviction to have } \\
\text { badly coped with the } \\
\text { situational demands, } \\
\text { which means } \\
\text { - not to know what the } \\
\text { situation exactly } \\
\text { demands, } \\
\text { - to have a negative, } \\
\text { pessimistic feeling in } \\
\text { handling the situation, } \\
\text { - to be sure that ones } \\
\text { own efforts had no } \\
\text { effect on improving the } \\
\text { situation. }\end{array}$ & $\begin{array}{l}\text { "that stroke my self } \\
\text { confidence; I thought } \\
\text { I'm a nothing - or even } \\
\text { less than that." }(5,34)\end{array}$ & $\begin{array}{l}\text { All three aspects of } \\
\text { definition point to low } \\
\text { self confidence, no } \\
\text { fluctuations } \\
\text { recognizable }\end{array}$ \\
\hline
\end{tabular}

Fig.3: Example for a coding agenda [16]

Category definitions, prototypical text passages, and rules for distinguishing different categories were formulated in respect to theory and material, are completed step by step, and are revised with the process of analysis. [17]

\section{Computer Programs for Support of Qualitative Content Analysis}

Especially within the last years several computer programs had been developed within the framework of qualitative analysis to support (not to replace) steps of text interpretation (cf. HUBER 1992; WEITZMAN \& MILES 1995; MAYRING 1996; FIELDING \& LEE 1998). The computer plays here a triple role:

- He works as assistant, supporting and making easier the steps of text analysis on screen (working through the material, underlining, writing marginal notes, defining category definitions and coding rules, recording comments on the material ...). He offers helpful tools handling the text (searching, jumping to different passages, collecting and editing passages ...). 
- He works as documentation center, recording all steps of analysis of all interpreters, making the analysis comprehensible and replicable (e.g. to trace back in the material causes of non-reliabilities between two coders).

- He offers links to quantitative analysis (often already implemented within the program), e.g. to compare frequencies of categories, without the dangers of errors in data transfer by hand to another computer program. [18]

Working with qualitative content analysis two computer programs had especially proved it's worth, ATLAS/ti and winMAX, which both are available in free demoversions (http://www.atlasti.de and http://www.winmax.de). [19]

\section{Examples of Projects Working with Qualitative Content Analysis}

To demonstrate the possibilities of qualitative content analysis we want to give some short examples of research projects working with the above explicated procedures:

- Sandro VICINI (1993) has conducted 14 open-ended in-depth interviews with educational advisors about concrete case-studies from their advisory service with the aim to reconstruct their theory of mind of advice. He used summarizing qualitative content analysis leading to eight main categories. The results were, that advice praxis had become therapy-oriented, that there are totally different concepts of advice, and that the advisors react highly professional. [20]

- Christa GERWIN (1993) made a diary study with 21 middle school teachers about their daily hassles and uplifts and analyzed the transcripts with summarizing qualitative content analysis. She could demonstrate, that being a teacher means severe stresses, from everyday problems with the copy machine to treating students with behavior disorders. [21]

- Klaus BECK and Gerhard VOWE (1995) have analyzed 25 media products (newspapers, journals, radio transmissions) concerning new multimedia approaches. With a combination of inductive and deductive qualitative content analysis they found patterns of argumentation like: euphoria about multimedia; economic optimism; political critic; apocalyptic predictions. [22]

- Claudia DOLDE and Klaus GOETZ (1995) have conducted 5 open-ended interviews with adult students in a on-job computer education studio. Working with inductive and deductive qualitative content analysis they analyzed their learning activities and learning strategies. The main advantage of the learning concept in the course seemed to be flexibility in time, as main disadvantage appeared heterogeneity of course members. [23]

- Joachim BAUER et al. (1998) analyzed the biographies of 21 Alzheimer disease patients to find out common patterns and to compare them with 11 vascular dement patients of the same age. The biographical interviews had been worked through with qualitative content analysis and led to typical biographical patterns (e.g. over-protecting social network) of the Alzheimer patients. [24] 
- In our own team we just finished a study on unemployment of teachers in the Eastern parts of Germany (MAYRING, KOENIG, BIRK \& HURST 2000). The material had been open-ended interviews and open-ended biographical questionnaire of 50 unemployed teachers, asking for their psycho-social stresses and coping behavior. The results had been compared with a former study on teacher unemployment in West Germany of our team. Inductive and deductive computer-assisted content analysis pointed out that the doubled crisis situation of the persons (unemployment and German unification) causes specific stresses and new chances for adaptation. [25]

\section{Discussion}

With the qualitative content analysis we wanted to describe procedures of systematic text analysis, which try to preserve the strengths of content analysis in communication science (theory reference, step models, model of communication, category leaded, criteria of validity and reliability) to develop qualitative procedures (inductive category development, summarizing, context analysis, deductive category application) which are methodological controlled. Those procedures allow a connection to quantitative steps of analysis if it seems meaningful for the analyst. [26]

The procedures of qualitative content analysis seem less appropriate,

- if the research question is highly open-ended, explorative, variable and working with categories would be a restriction, or

- if a more holistic, not step-by-step ongoing of analysis is planned. [27]

On the other hand qualitative content analysis can be combined with other qualitative procedures. The research question and the characteristics of the material should have the priority in the decision about adapted methods. So it would be in my opinion better to discuss questions about methods in respect to specific content areas (cf. coping of illness MAYRING 1994b; emotion research SCHMITT \& MAYRING 2000) and then to compare different methodological approaches (quantitative approaches as well). [28]

\section{References}

Altheide, D.L. (1996). Qualitative media analysis. Qualitative Research Methods Vol. 38. Thousand Oaks: Sage.

Ballstaedt, S.-P.; Mandl, H.; Schnotz, W. \& Tergan, S.-O. (1981). Texte verstehen, Texte gestalten. München: Urban \& Schwarzenberg.

Bauer, J.; Qualmann, J.; Stadtmüller, G. \& Bauer, H. (1998). Lebenslaufuntersuchungen bei Alzheimer-Patienten: Qualitative Inhaltsanalyse prämorbider Entwicklungsprozesse. In Kruse, A. (Ed.), Psychosoziale Gerontologie. Band 2: Intervention (pp.251-274). Göttingen: Hogrefe.

Beck, K. \& Vowe, G. (1995). Multimedia aus der Sicht der Medien. Argumentationsmuster und Sichtweisen in der medialen Konstruktion. Rundfunk und Fernsehen, 43, 549-563.

Becker, J. \& Lißmann, H.-J. (1973). Inhaltsanalyse - Kritik einer sozialwissenschaftlichen Methode. Arbeitspapiere zur politischen Soziologie 5. München: Olzog.

Berelson, B. (1952). Content analysis in communication research. Glencoe, III.: Free Press. 
Dijk van, T.A. (1980). Macrostructures. Hillsdale, N.J.: Erlbaum.

Dolde, C. \& Götz, K. (1995). Subjektive Theorien zu Lernformen in der betrieblichen DVQualifizierung. Unterrichtswissenschaft, 23, 264-287.

Fielding, N.G. \& Lee, R.M. (1998). Computer analysis and qualitative research. London: Sage.

Gerbner, G.; Holsti, O.R.; Krippendorff, K.; Paisley, W.J.\& Stone, Ph.J. (Eds.) (1969). The analysis of communication content. New York: Wiley.

Gerwin, C. (1994). Streß in der Schule - Belastungswahrnehmung von Lehrerinnen und Lehrern. Zeitschrift für Pädagogische Psychologie, 8, 41-53.

Huber, G.L. (Ed.) (1992). Qualitative Analyse. Computereinsatz in der Sozialforschung. München: Oldenbourg Verlag.

Kracauer, S. (1952). The challenge of qualitative content analysis. Public Opinion Quarterly, 16, 631-642.

Krippendorff, K. (1969). Models of messages: three prototypes. In G. Gerbner, O.R. Holsti, K. Krippendorff, G.J. Paisly \& Ph.J. Stone (Eds.), The analysis of communication content. New York: Wiley.

Krippendorff, K. (1980). Content analysis. An Introduction to its Methodology. Beverly Hills: Sage.

Mayring. Ph. (1994a). Qualitative Inhaltsanalyse. In A. Böhm, A. Mengel \& T. Muhr (Eds.), Texte verstehen: Konzepte, Methoden, Werkzeuge (pp.159-176). Konstanz: Universitätsverlag.

Mayring, Ph. (1994b). Qualitative Ansätze in der Krankheitsbewältigungsforschung. In E. Heim \& M. Perrez, (Eds.), Krankheitsverarbeitung. Jahrbuch der Medizinischen Psychologie 10 (pp.38-48). Göttingen: Hogrefe.

Mayring, Ph. (1996). Einführung in die qualitativer Sozialforschung. Eine Anleitung zu qualitativem Denken (3rd edition). Weinheim: Psychologie Verlags Union.

Mayring, Ph. (2000). Qualitative Inhaltsanalyse. Grundlagen und Techniken (7th edition, first edition 1983). Weinheim: Deutscher Studien Verlag.

Mayring, Ph.; König, J.; Birk, N. \& Hurst, A. (2000). Opfer der Einheit. Eine Studie zur Lehrerarbeitslosigkeit in den neuen Bundesländern. Opladen; Leske \& Budrich.

Merten, K. (1983). Inhaltsanalyse. Einführung in Theorie, Methode und Praxis. Opladen: Westdeutscher Verlag.

Mostyn, B. (1985). The content analysis of qualitative research data: A dynamic approach. In M. Brenner, J. Brown \& D. Cauter (Eds.), The research interview (pp.115-145). London: Academic Press.

Pool, J.d.S. (1959). Trends in content analysis. Urbana: University of Illinois Press.

Ritsert, J. (1972). Inhaltsanalyse und Ideologiekritik. Ein Versuch über kritische Sozialforschung. Frankfurt: Athenäum.

Rust, H. (1983). Inhaltsanalyse. Die Praxis der indirekten Interaktionsforschung in Psychologie und Psychotherapie. München: Urban \& Schwarzenberg.

Schmitt, A. \& Mayring, Ph. (2000, in press). Qualitativ orientierte Methoden. In J.H. Otto, H.A. Euler \& H. Mandl. (Eds.), Handbuch Emotionspsychologie. Weinheim: Psychologie Verlags Union.

Ulich, D.; Haußer, K.; Mayring, Ph.; Strehmel, P.; Kandler, M. \& Degenhardt, B. (1985).

Psychologie der Krisenbewältigung. Eine Längsschnittuntersuchung mit arbeitslosen Lehrern. Weinheim: Beltz.

Vicini, S. (1993). Subjektive Beratungstheorien. Bernische Erziehungsberaterlnnen reflektieren ihre Praxis. Bern: Lang.

Weitzmann, E.A. \& Miles, M.B. (1995). Computer Programs for Qualitativ Data Analysis. Newbury Park: Sage.

Wittkowski, J. (1994). Das Interview in der Psychologie. Interviewtechnik und Codierung von Interviewmaterial. Opladen: Westdeutscher Verlag.

\section{Author}




\section{Citation}

Mayring, Philipp (2000). Qualitative Content Analysis [28 paragraphs]. Forum Qualitative Sozialforschung / Forum: Qualitative Social Research, 1(2), Art. 20, http://nbnresolving.de/urn:nbn:de:0114-fqs0002204.

Revised 2/2009 